\title{
Spatial Zonation and Diversity of Bivalves and Gastropods in Mangrove Forests of Casiguran, Aurora, Philippines
}

\author{
Maria Cristina B. Cañada, Eutiquio L. Rotaquio, Jr., RB J. Gallego \\ Department of Graduate Studies, Aurora State College of Technology, Baler, Aurora, Philippines \\ Email: mariacristinacanada@ascot.edu.ph
}

How to cite this paper: Cañada, M.C.B., Rotaquio Jr., E.L. and Gallego, RB.J. (2021) Spatial Zonation and Diversity of Bivalves and Gastropods in Mangrove Forests of Casiguran, Aurora, Philippines. Open Journal of Ecology, 11, 645-663.

https://doi.org/10.4236/oje.2021.1110041

Received: March 3, 2021

Accepted: September 27, 2021

Published: September 30, 2021

Copyright $\odot 2021$ by author(s) and Scientific Research Publishing Inc. This work is licensed under the Creative Commons Attribution International License (CC BY 4.0).

http://creativecommons.org/licenses/by/4.0/

\begin{abstract}
This study generally aimed to determine the spatial zonation and diversity of bivalves and gastropods in mangrove forest of Cozo, Esteves and Tinib in Casiguran, Aurora. Specifically, this aimed to determine the species composition and distribution, and determine the relationship between spatial zonation and diversity of bivalves and gastropods as influenced by ecological factors such as vegetation, soil texture, organic matter, soil salinity, and soil $\mathrm{pH}$. A total of 22 taxa comprising eight species of bivalves and 14 species of gastropods were identified. The high tidal zone of Esteves had high diversity (0.66) of bivalve species compared to other tidal zones and areas. On the other hand, the diversity of gastropods was almost equal in the middle tidal zones of Cozo (0.60), Esteves (0.57), and Tinib (0.42). In terms of bivalve species' density and abundance, Dendostrea folium was the most dense and abundant in the low tidal zone of Cozo $\left(253,333\right.$ ind.ha ${ }^{-1}$ or 25 ind. $\left.\mathrm{m}^{2-1}, 97.44 \%\right)$ while Gafrarium tumidum in the low tidal zones of Esteves $\left(46,666\right.$ ind.ha ${ }^{-1}$ or 4 ind. $\left.\mathrm{m}^{2-1}, 73.68 \%\right)$ and Tinib $\left(126,666\right.$ ind $\cdot \mathrm{ha}^{-1}$ or 12 ind. $\left.\mathrm{m}^{2-1}, 50 \%\right)$. In terms of gastropod species' density and abundance, Cerithidea cingulata was the most dense and abundant in the low tidal zone $\left(666,666\right.$ ind $\cdot \mathrm{ha}^{-1}$ or 66 ind. $\left.\mathrm{m}^{2-1}, 65.79 \%\right)$ of Cozo and the middle tidal zone $\left(5,280,000\right.$ ind $\cdot \mathrm{ha}^{-1}$ or 528 ind. $\left.\mathrm{m}^{2-1}, 61.40 \%\right)$ of Tinib. It was Terebralia palustris in the low tidal zone $\left(1,263,333\right.$ ind $\cdot \mathrm{ha}^{-1}$ or 126 ind. $\left.\mathrm{m}^{2-1}, 63.06 \%\right)$ of Esteves. All tidal zones within each study area had greater dissimilarities in terms of bivalves but had greater similarities in terms of gastropod species' compositions. On the other hand, all tidal zones between study areas had greater dissimilarities in terms of bivalve and gastropod species present. Most tidal zones had Gafrarium tumidum as common bivalve species while Neritidae sp. and Cerithidea cingulata were common gastropod species. All these species were found thriving in a wide range of vegetation, soil texture, organic matter, soil salinity and $\mathrm{pH}$.
\end{abstract}




\section{Keywords}

Spatial Zonation, Diversity, Bivalves, Gastropods, Mangrove Forest

\section{Introduction}

Mangrove forest functions as habitat and feeding ground for bivalves and gastropods. The roots serve as shelter during high tide since these organisms require a hard substrate for anchoring while they filter feed. The leaf litter serves as source of nutrient-rich organic matter making these organisms an important link in the transfer of organic matter from man groves to the third trophic level such as fish and birds [1]. As a feeding ground, this forest plays a significant role in the diversity and abundance of bivalves and gastropods as dominant macrofauna in the ecosystem. The diversity and abundance of these organisms in turn will serve bioindicators of the changing habitat of a mangrove ecosystem [2].

Bilvalves and gastropods are invertebrate animals that live in both marine and freshwater habitats. These organisms can be found in high tidal zones to abyssal depth. In high tidal zone where mangroves forests exist, these organisms also exist and are gleaned by coastal dwellers. In fact, in the mangrove forests in Casiguran, Aurora bivalves and gastropod species are regularly gleaned by coastal dwellers within and between different tidal zones. These organisms have been observed to be distributed in a particular pattern within the mangrove forests and its zonation is revealed to be influenced by the vertical gradient caused by tide and the horizontal gradient caused by wave action [3]. These species serve as food and source of income to the community. In fact, prior informal interviews with the locals reveal that gleaning activities are parts of their lives with larger species collected in abundance before as compared nowadays where there are smaller and fewer species.

A database as to what particular species of bivalves and gastropods are present in the area including their diversity before a particular species will become extinct must be established. In addition, the data as to what species can be found in different established tidal zones in relation to different ecological factors could be used by concern agencies in the formulation of management plan for the conservation of not just for these bivalves and gastropods but as well as for the mangrove forests where these species live.

This study therefore, determined the spatial zonation and diversity of bivalves and gastropods in mangrove forests of Cozo, Esteves and Tinib in Casiguran, Aurora. Specifically, this determined the species composition and distribution of bivalves and gastropods and determined the relationship between spatial zonation and diversity of bivalves and gastropods as influenced by ecological factors such as vegetation, soil texture, organic matter, soil salinity, and soil $\mathrm{pH}$. 


\section{Materials and Methods}

\subsection{The Study Site}

This study was conducted to provide information as to the spatial zonation and diversity of bivalves and gastropods in relation to ecological factors in mangrove forests of Cozo, Esteves and Tinib in Casiguran, Aurora (Figure 1). This was conducted in January to February 2016.

The Cozo sampling area $\left(\mathrm{N} 16^{\circ} 15^{\prime} 37^{\prime \prime} \mathrm{E} 122^{\circ} 08^{\prime} 41^{\prime \prime}\right)$ is part of a continuous stretch of mangrove forest that starts from Lual on its southern side to San Ildefonso on its northern side. The mangrove forest has Mabungtot River that flows on its southern side as it discharges to the ocean. The area is rich in mature mangrove trees with plenty of wildlings below in all tidal zones.

The Esteves sampling area (N16 $\left.11^{\prime} 16^{\prime \prime} \mathrm{E} 122^{\circ} 03^{\prime} 07^{\prime \prime}\right)$ is part of a continuous stretch of mangrove forest that starts from Calabgan on its southern part to Dibet on its northern part. This is partially enclosed by the Calabgan River that flows in front of the high tidal zone going on its northern side as it discharges to the ocean. The mangrove forest is composed of mature trees with very few scattered

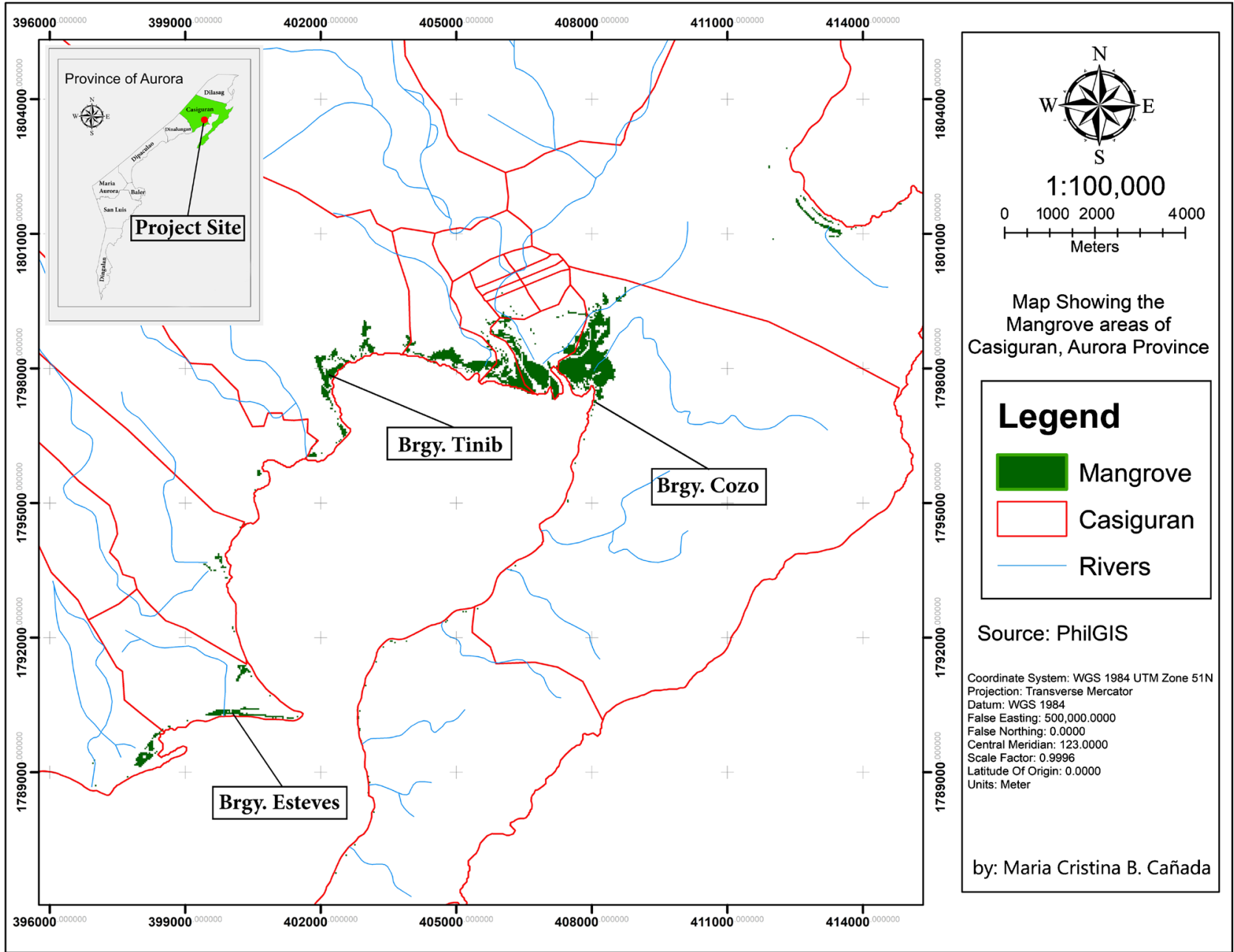

Figure 1. Location of the study sites. 
population of wildlings.

The Tinib sampling area $\left(\mathrm{N} 16^{\circ} 15^{\prime} 34^{\prime \prime} \mathrm{E} 122^{\circ} 05^{\prime} 07^{\prime \prime}\right)$ is part of a continuous stretch of mangrove forest from Dibacong in the southern part to Calangcuasan in the northern part of Casiguran. The mangrove forest is composed of different characteristic habitat; e.g. the low tidal zone is dominated with wildlings, the middle tidal zone of mature with plenty scattered young wildlings below, while the high tidal zone is composed of matures trees with sparse population of wildlings. The sampling area is partially enclosed on its sides with the forking Montay River as it discharges to the ocean adding differences in salinity between intertidal zones.

Based on informal interview with the locals, the mangrove forest in Casiguran is the most gleaned area where majority of bivalves and gastropods sellers are coming from this municipality. In fact, the locals have noted that even other residents from nearby towns would come into this area to glean believing that there are plenty of palatable species that can be found than those areas where they come from.

\subsection{Data Gathering Procedures}

Three transect lines measuring $150 \mathrm{~m}$ were laid perpendicular to the intertidal zone using a meter tape. The distance between each transect line was $100 \mathrm{~m}$ parallel to the intertidal zone Three sampling stations (low tidal zone, middle tidal zone, and high tidal zone) were established in each transect line. The center of each sampling station was laid with $1 \mathrm{~m} \times 1 \mathrm{~m}$ wooden quadrat. A total of $3 \mathrm{~m}^{2}$ was covered for each zone equivalent to $9 \mathrm{~m}^{2}$ for every area. The GPS reading for each intertidal zone was obtained using Garmin E-trex 10.

The collection of specimen was done by handpicking of epifaunal species found on soil surface, exposed roots, stems, and leaves. This was also done by turning over rocks and fresh fallen leaves. Infaunal species were collected by raking the substrate using a small garden rake up to $15 \mathrm{~cm}$ depth. Each species present in each quadrat was identified, counted, and tabulated in a field notebook using a pencil. The data tabulated include the family name, scientific name, local name, number of quadrats each species found, number of individuals of each species, total number of species and the dominant vegetation within each intertidal zone.

Representative samples of each species were collected and placed in a plastic bag with a label for authentication of identification by an expert from SEAFDEC. Species collected in each quadrat were identified in situ using books by [4] [5] [6]. The representative samples collected were photographed using Nikon D7000 and were sent to the expert for authentication of identification.

Soil samples were collected at the center of each tidal zone in each transect line. Three soil samples for each tidal zone with a total of nine soil samples in each study area were collected. Soil collection was done by digging the soil using a small garden spade up to a depth of $20 \mathrm{~cm}$ as measured using a ruler. The samples were then placed inside each plastic bag with specific label which were in 
turn placed inside each net bag to secure the samples while being transported from the study site to the soil laboratory.

The soil texture and percent organic matter were analyzed at the soil laboratory of the Department of Agriculture Regional Field Office III located at Sto. Niño Capitol Compound, City of San Fernando, Pampanga.

A modified procedure [7] was used for soil salinity.

The soil $\mathrm{pH}$ was measured using a digital $\mathrm{pH}$ meter. A $30 \mathrm{~g}$ soil sample was placed into the beaker and then added with $30 \mathrm{ml}$ of distilled water. This was stirred for one minute every three minutes (repeated three times) to obtain a soil slurry. The $\mathrm{pH}$ meter was then placed in the soil slurry and the reading was recorded in a notebook using a pencil. Finally, the $\mathrm{pH}$ meter was washed with distilled water and dried with tissue paper. This procedure was repeated in each of the remaining soil samples.

\subsection{Statistical Tools Used}

This study used descriptive statistics. The specific formula in the computation of data was the following:

1) Species diversity was computed using the Shannon's diversity index:

$$
H=-\sum_{i=1}^{s} p_{i} \ln p_{i}
$$

where:

$s=$ total number of species in the community.

$p_{i}=$ proportion of $s$ made up of the ith species.

For simplicity of discussion, the index was categorized into:

$\begin{array}{ll}\text { Very high } & 0.81-1.0 \\ \text { High } & 0.61-0.80 \\ \text { Almost high } & 0.41-0.60 \\ \text { Slightly low } & 0.21-0.39 \\ \text { Very low } & 0.01-0.20 \\ \text { Perfectly low } & 0\end{array}$

2) Species equitability was computed using Shannon's equitability index:

$$
E H=H / I n S
$$

where:

$H=$ Shannons diversity index.

$S=$ total number of species.

For simplicity of discussion, the index was categorized into:

$\begin{array}{ll}\text { Very equal } & 0.81-1.0 \\ \text { Equal } & 0.61-0.80 \\ \text { Almost equal } & 0.41-0.60 \\ \text { Slightly unequal } & 0.21-0.39 \\ \text { Very unequal } & 0.01-0.20 \\ \text { Perfectly unequal } & 0.00\end{array}$


3) The population density per species was calculated based on the index $(D)$ :

$$
D=\frac{n_{i}}{A}
$$

where:

$n_{i}=$ total number of individuals per species.

$A=$ total area covered in hectares.

4) The relative abundance per species was computed based on the index $(\% A b)$ :

$$
\% A b=\frac{D}{\sum D}
$$

where:

$D=$ population density per species.

$\sum D=$ the sum total of all population densities of all species.

5) The similarity between mangrove tidal zones and sampling areas in terms of bivalve and gastropod species was computed using Sorensen's similarity index:

$$
Q S=\frac{2 C}{A+B}
$$

where:

$C=$ number of species common to both tidal zones.

$A$ and $B=$ number of species in tidal zone $\mathrm{A}$ and tidal zone $\mathrm{B}$.

For simplicity of discussion, the index was categorized into:

$\begin{array}{ll}\text { Very similar } & 0.81-1.0 \\ \text { Similar } & 0.61-0.80 \\ \text { Almost similar } & 0.41-0.60 \\ \text { Dissimilar } & 0.21-0.39 \\ \text { Very dissimilar } & 0.01-0.20 \\ \text { Perfectly dissimilar } & 0.00\end{array}$

6) The relationship between spatial zonation and diversity of bivalves and gastropods in relation to ecological factors such as vegetation, soil texture, organic matter, soil salinity and soil $\mathrm{pH}$ was described based on principal component analysis (PCA). PCA is used to compute the principal components and using them to perform a change of basis on the data.

\section{Results and Discussion}

\subsection{Species Composition and Distribution}

Table 1 shows the list of bivalve and gastropod species found in mangrove forests of Cozo, Esteves, and Tinib in Casiguran, Aurora (Figure 1). A total of 22 taxa comprising eight species of bivalves and 14 species of gastropods were identified. The bivalves belong to five families with three families represented by a single species. On the other hand, the gastropods belong to seven families with four families represented by a single species, two families represented by four 
Table 1. List of bivalve and gastropod species found in mangrove forests of Cozo, Esteves, and Tinib, Casiguran, Aurora.

\begin{tabular}{|c|c|c|c|}
\hline Family Name & Scientific Name & Local Name & Distribution \\
\hline \multicolumn{4}{|c|}{ Bivalves } \\
\hline Laternulidae & Laternula truncata & Sugisog & * \\
\hline Mytilidae & Modiolus aratus & Ubet ng agta & * \\
\hline \multirow[t]{2}{*}{ Ostreidae } & Dendostrea folium & Sise & $* *$ \\
\hline & Saccostrea cuccullata & Sise & * \\
\hline Tellinidae & Pistris truncata & & $*$ \\
\hline \multirow[t]{4}{*}{ Veneridae } & Gafrarium tumidum & Parek & ** \\
\hline & Katelysia japonica & Gume & * \\
\hline & Pitar citrinus & Gume-gumean & $*$ \\
\hline & \multicolumn{3}{|c|}{ Gastropods } \\
\hline Littorinidae & Littoraria scabra & & **4 \\
\hline \multirow[t]{2}{*}{ Nassariidae } & Hebra corticata & & ** \\
\hline & Nassarius pullus & & * \\
\hline Naticidae & Polinices mammilla & Bulan-bulan & * \\
\hline \multirow[t]{4}{*}{ Neritidae } & Nerita albicilla & Kate & * \\
\hline & Nerita chameleon & Kate & * \\
\hline & Neritidae sp. & & $* \star+$ \\
\hline & Neritina turrita & Angloy & * \\
\hline Melongenidae & Volema myristica & Alan-alan & $* *$ \\
\hline Muricidae & Muricidae $s p$ & & $\uparrow$ \\
\hline \multirow[t]{4}{*}{ Potamididae } & Cerithidea cingulata & Balilit & $* \star \leftarrow$ \\
\hline & Terebralia palustris & Balilit & * \\
\hline & Terebralia sulcata & Balilit & $* *$ \\
\hline & Telescopium telescopium & Susong dalaga & 4 \\
\hline
\end{tabular}

* $=$ Cozo ${ }^{*}=$ Esteves $\uparrow=$ Tinib.

species each and one family represented by two species.

Most of the species (17) were collected in Esteves mangrove forest which was dominated by mature mangrove trees in low and middle tidal zones with scattered newly planted seedlings in the high tidal zone. Most bivalves in this area were associated to sandy loam substratum of the high tidal zone which contains higher percentage of sand as compared to sandy loam soils of Cozo and Tinib. The high tidal zone was possibly preferred by bivalves since this was always moist being near a river aside from containing less root branching as it could be impossible for the soft fleshy feet of infaunal bivalves to penetrate root masses of mangrove [8]. On the other hand, most epifaunal bivalve species (Dendostrea folium and Saccostrea cuccullata) were found adhered to roots and stems of 
mangrove trees as also observed in Cozo and Tinib.

Most species of gastropods were collected in Esteves which were found either grazing in the soil surface or attached in mangrove roots and stems as also seen in Cozo and Tinib.

The gastropod species that were exclusive to the mangrove habitat were members of the family Littorinidae (Littoraria scabra) and family Potamididae (Cerithidea cingulata, Terebralia palustris, Terebralia sulcata and Telescopium telescopium). Similar species were also collected in the mangrove zones of Catanduanes province [9].

\subsection{Species Diversity and Equality}

Table 2 shows the diversity of bivalve and gastropod species in different tidal zones in Cozo, Esteves, and Tinib mangrove forests. There were only two species of bivalves found in Cozo which were both present in the low tidal zone that explained the very low (0.05) diversity. Similarly, all four bivalve species (Table 1 ) in Tinib were found in the low tidal zone resulting to the slightly low (0.34) diversity. This is because frequent tidal inundation in the low tidal zone favors the growth of benthic microalgae and macroalgae that serves as food for filter and deposit feeder as in the case of bivalves, thus, favoring their presence in this zone [10].

On the other hand, in Esteves, the highest diversity of bivalve species (0.66) was recorded in the high tidal zone. The substrate in this zone was frequently moist as this was near the river, thus, favoring the growth of microalgae that in turn favored the growth of bivalves. These bivalves were suited to this mudflat where it lies partially buried in the sandy loam sediment. On the other hand, the low and middle tidal zones had slightly low diversities $(0.37$ and 0.24$)$ that could be attributed to its dry condition during low tide that could result to desiccation of the species.

The gastropod species found in Cozo and Esteves had high diversities (0.60 and 0.57$)$ while Tinib had almost high diversity (0.42) in the middle tidal zones

Table 2. Diversity of bivalve and gastropod species in different tidal zones in Cozo, Esteves, and Tinib mangrove forests.

\begin{tabular}{cccc}
\hline \multirow{2}{*}{ Sampling Area } & \multicolumn{3}{c}{ Species Diversity $(H)$} \\
\cline { 2 - 4 } & Low & Middle & High \\
\hline Cozo & 0.05 & Bivalves \\
Esteves & 0.37 & 0.00 & 0.00 \\
Tinib & 0.34 & 0.24 & 0.66 \\
& & 0.00 & 0.00 \\
\hline Cozo & 0.39 & Gastropods & 0.47 \\
Esteves & 0.37 & 0.60 & 0.45 \\
Tinib & 0.34 & 0.57 & 0.38 \\
\hline
\end{tabular}


of all study areas. These could be explained by the presence of diverse range of microhabitat within this zone. For example, in Cozo the soil texture was either sandy loam or loam while in Tinib it was sandy loam or sandy clay loam. In addition, the middle tidal zone had more mature mangrove trees providing more roots branching underground that served as anchor for gastropods during high tide aside from providing shelter to the soil, thus, reducing its rate of drying during low tide.

The slightly low diversity (0.39) in the low tidal zone of Cozo could be due to the fact that this zone was dominated by mangrove saplings providing less anchor to gastropods that tend to either cling to roots and stems or climb up mangrove trees during high tide. On the other hand, the almost low diversity in the high tidal zone could be due to the low $(0.23 \%$ to $2.00 \%)$ organic matter content aside from the loam and sandy loam soils with high percentage of clay $(17.94 \%$ to $23.79 \%)$ and silt (10.40\% to $34.02 \%)$ providing poor aeration in the soil.

The low tidal zone of Esteves was of slightly low diversity (0.37) while the high tidal zone was almost high (0.45). The almost high diversity in the high tidal zone was due to its almost always moist soil being near a river thus favoring the growth of algae that served as food for gastropods.

In Tinib, both low and high tidal zones were slightly low in diversity (0.34 and 0.38 ). This slightly low diversity in the high tidal zone could be due to reduced frequency in tidal inundation that resulted to a drier environment which was less suitable for the growth of algae and thus reduced availability of food for the gastropods.

Table 3 shows the equitability of distribution of bivalves and gastropods species in different tidal zones in Cozo, Esteves, and Tinib mangrove forests. The distribution of bivalve species in the low tidal zone of Cozo is very unequal (0.17). This can be explained by the presence of large number of Dendostrea folium in the area found attached to the stems of young mangrove trees.

In the case of Esteves, the distribution of species within the low and middle

Table 3. Equitability of distribution of bivalve and gastropod species in different tidal zones in Cozo, Esteves, and Tinib mangrove forests.

\begin{tabular}{cccc}
\hline \multirow{2}{*}{ Sampling Area } & \multicolumn{3}{c}{ Species Equitability $(E H)$} \\
\cline { 2 - 4 } & Low & Middle & High \\
\hline Cozo & 0.17 & Bivalves \\
Esteves & 0.62 & 0.00 & 0.00 \\
Tinib & 0.59 & 0.80 & 0.94 \\
& & 0.00 & 0.00 \\
\hline Cozo & 0.56 & Gastropods & 0.67 \\
Esteves & 0.42 & 0.77 & 0.50 \\
Tinib & 0.44 & 0.63 & 0.43 \\
\hline
\end{tabular}


tidal zones (0.62 and 0.80) were equal as most species were represented in these zones. On the other hand, the high tidal zone had very equal (0.94) distribution although Gafrarium tumidum had greater number of individuals as compared to other species. This result could be attributed to the sandy loam sediment that is mostly wet as bivalves cannot withstand long period of exposure to air and drier environment. In addition, higher $\mathrm{pH}(7.6)$ could also be a factor as lower $\mathrm{pH}$ could result to bivalves exterior exoskeleton and shell erosion [11].

In Tinib, species distribution was almost equal (0.59) in the low tidal zone. This could be due to the fact that all bivalve species found in the area during this survey were all represented in this zone.

For gastropods species, their distribution was almost equal (0.56) in the low tidal zone of Cozo while it was equal in the middle (0.77) and high (0.67) tidal zones. This equal distribution was expected as most gastropod species found in these zones were either grazing on organic matter on soil or attached to pneumatophores and stems feeding on algae.

In Esteves, there was almost equal distribution in the low (0.42) and high (050) tidal zones. However, the middle (0.63) tidal zone had equal distribution due to the presence of more mangrove trees that served as anchor during high tide, thus, most species preferred this zone. In addition, gastropod species can live both on the ground and on the trees. In fact, the presence of closely distributed population of mangrove trees provided a suitable habitat for gastropods where they could either climb to tree or stay covered and clustered around the roots branching on the ground during high tide. For example, the Littoraria scabra is often found among tropical mangrove roots, trunks, and leaves and tend to move up and down with the tide to avoid immersion [12].

In addition, the close population of mangrove trees in the middle tidal zone provided more varied trophic position of the gastropods. For example, a sediment dweller, Cerethidea cingulata feed selectively on organic matter or mycrophytobenthos, while a grazer, Littoraria sp. feed on epiphytic algae on tree trunks or pneumatophores [13].

In Tinib, the low (0.44), middle (0.48) and high (0.43) tidal zones had almost equal distribution. This distribution was influenced by the large number of Neritidae sp. and Cerithidea cingulata in slightly saline to medium salinity.

\subsection{Density and Abundance}

Figure 2 shows the density of bivalve species in different tidal zones of Cozo, Esteves and Tinib mangrove forests. In Cozo, Dendostrea folium emerged as densest species in the low $\left(253,333\right.$ ind $\cdot \mathrm{ha}^{-1}$ or 25 ind. $\left.\mathrm{m}^{2-1}\right)$ and middle $(90,000$ ind $\cdot \mathrm{ha}^{-1}$ or 9 ind. $\mathrm{m}^{2-1}$ ) tidal zones. This species was found attached to mangrove saplings feeding on algae attached on the stems and grazing on young leaves that were abundant on the said zones. In addition, the species density could also be attributed to the salinity level $(7.4 \mathrm{ppt}$ to $7.6 \mathrm{ppt})$ and organic matter content $(0.19 \%$ to $2.84 \%)$. 

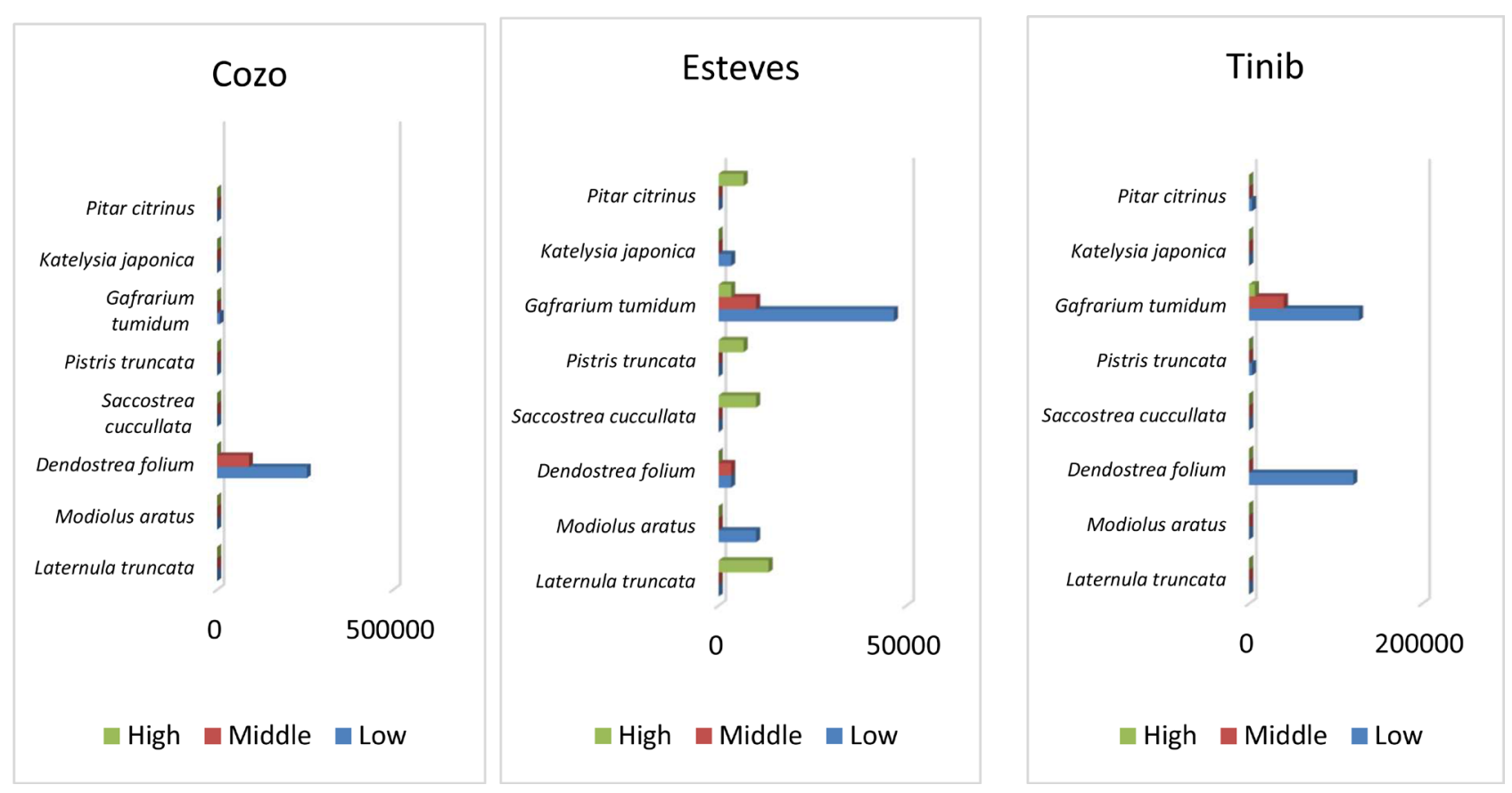

Figure 2. Density of bivalve species in different tidal zones of Cozo, Esteves, and Tinib mangrove forests.

In Esteves, Gafrarium tumidum was the densest species (46,666 ind $\cdot \mathrm{ha}^{-1}$ or 4 ind. $\left.\mathrm{m}^{2-1}\right)$ in its low tidal zone. This species was commonly found buried in sandy clay to sandy loam soil with high percentages of sand $(56.75 \%$ to $80.50 \%)$ that provided good oxygen for this infaunal species. The density of this species was followed by Modiolus aratus $\left(10,000\right.$ ind $\cdot \mathrm{ha}^{-1}$ or 1 ind. $\left.\mathrm{m}^{2-1}\right)$ which was only found in Esteves mangrove forest. This species was seen present in sandy loam soil with high percentage of sand (80.46\% to $80.50 \%)$ as compared with other tidal zones within Esteves and between study sites. Gafrarium tumidum and Modiolus aratus were observed as commonly gleaned species by nearby coastal dwellers in this area.

In the middle tidal zone, still Gafrarium tumidum $\left(10,000\right.$ ind $\cdot \mathrm{ha}^{-1}$ or 1 ind. $\left.\mathrm{m}^{2-1}\right)$ was densest although in the high tidal zone it was Laternula truncata $\left(13,333\right.$ ind $\cdot \mathrm{ha}^{-1}$ or 1 ind. $\left.\mathrm{m}^{2-1}\right)$. The latter species preferred the moist habitat of sandy loam soil with salinity range between $5 \mathrm{ppt}$ to $6 \mathrm{ppt}$ and a $\mathrm{pH}$ of 7.6.

In Tinib, the low $\left(126,666\right.$ ind $\cdot \mathrm{ha}^{-1}$ or 12 ind. $\left.\mathrm{m}^{2-1}\right)$, middle $\left(40,000\right.$ ind $\cdot \mathrm{ha}^{-1}$ or 4 ind. $\left.\mathrm{m}^{2-1}\right)$, and high $\left(6,666\right.$ ind.ha $\left.^{-1}\right)$ tidal zones had Gafrarium tumidum as the densest species. This implies that this species can tolerate varied microclimatic conditions although it was found as most dense in the low tidal zone that had sandy loam soil with high percentage of sand (70.66\% to $72.52 \%)$ compared to the other zones within Tinib that provides good aeration in the soil as anoxic condition could be detrimental to all bivalves. This species was also found thriving in soil with organic matter ranging from $0.49 \%$ to $2.18 \%$, salinity ranging between $6 \mathrm{ppt}$ to $10 \mathrm{ppt}$ and $\mathrm{pH}$ between 7.2 to 7.4. This implied that this species is a generalist, thus, can be found in all tidal zones.

Figure 3 shows the density of gastropods species in different tidal zones of 
Cozo, Esteves and Tinib mangrove forests. The densest species in Cozo in the low $\left(666,666\right.$ ind $\cdot \mathrm{ha}^{-1}$ or 66 ind. $\left.\mathrm{m}^{2-1}\right)$ and high $\left(306,666\right.$ ind $\cdot \mathrm{ha}^{-1}$ or 30 ind. $\left.\mathrm{m}^{2-1}\right)$ tidal zones was Cerithidea cingulata. This species was found either grazing on the soil organic matter or seen attached to pneumatophores and saplings feeding with algae. The presence of abundant pneumatophores and saplings provided a favorable feeding habitat for this organisms. Aside from this, Cerithidea cingulata is a strict mangrove inhabitant species that breeds all year round that could explain its density in this study area. This species was also observed in all tidal zones with loam, sandy loam and sandy clay loam soils.

In the middle tidal zone, the densest species was Neritidae sp. $(283,333$ ind.ha $\mathrm{a}^{-1}$ or 28 ind. $\mathrm{m}^{2-1}$ ). This is a facultative species that tend to live both in mangrove and coastal areas. In fact, there were no adult Neritidae sp. found during the survey, thus, it was assumed that the mangrove forest had served as breeding ground while adult individuals went back to the coastal area.

On the other hand, the densest species in Esteves was Terebralia palustris which was found grazing on soil organic matter and algae in low $(1,263,333$ ind.ha $\mathrm{a}^{-1}$ or 126 ind. $\left.\mathrm{m}^{2-1}\right)$ to middle $\left(483,333\right.$ ind $\cdot \mathrm{ha}^{-1}$ or 48 ind. $\left.\mathrm{m}^{2-1}\right)$ tidal zones. The presence of this species in these zones could be attributed to the abundant pneumatophores of mature mangrove trees that serve as shelter during high tide. In fact, this species was observed clustered around either at the base of the stem or mangrove aerial roots. The high tidal zone had Neritidae sp. $\left(426,666\right.$ ind $\cdot h^{-1}$ or 42 ind. $\mathrm{m}^{2-1}$ ) as the most dense.

In Tinib, Cerithidea cingulata was the most dense in low $\left(4,170,000\right.$ ind $^{-h^{-1}}$ or 417 ind. $\left.\mathrm{m}^{2-1}\right)$, middle $\left(5,280,000\right.$ ind $\cdot \mathrm{ha}^{-1}$ or 528 ind. $\left.\mathrm{m}^{2-1}\right)$, and high $(3,926,666$ ind.ha $\mathrm{a}^{-1}$ or 392 ind. $\mathrm{m}^{2-1}$ ) tidal zones. The density of this species could be due to its ability to thrive in loam, sandy loam, and sandy clay loam soils, breed all year round and being a strict inhabitant of mangrove forest.

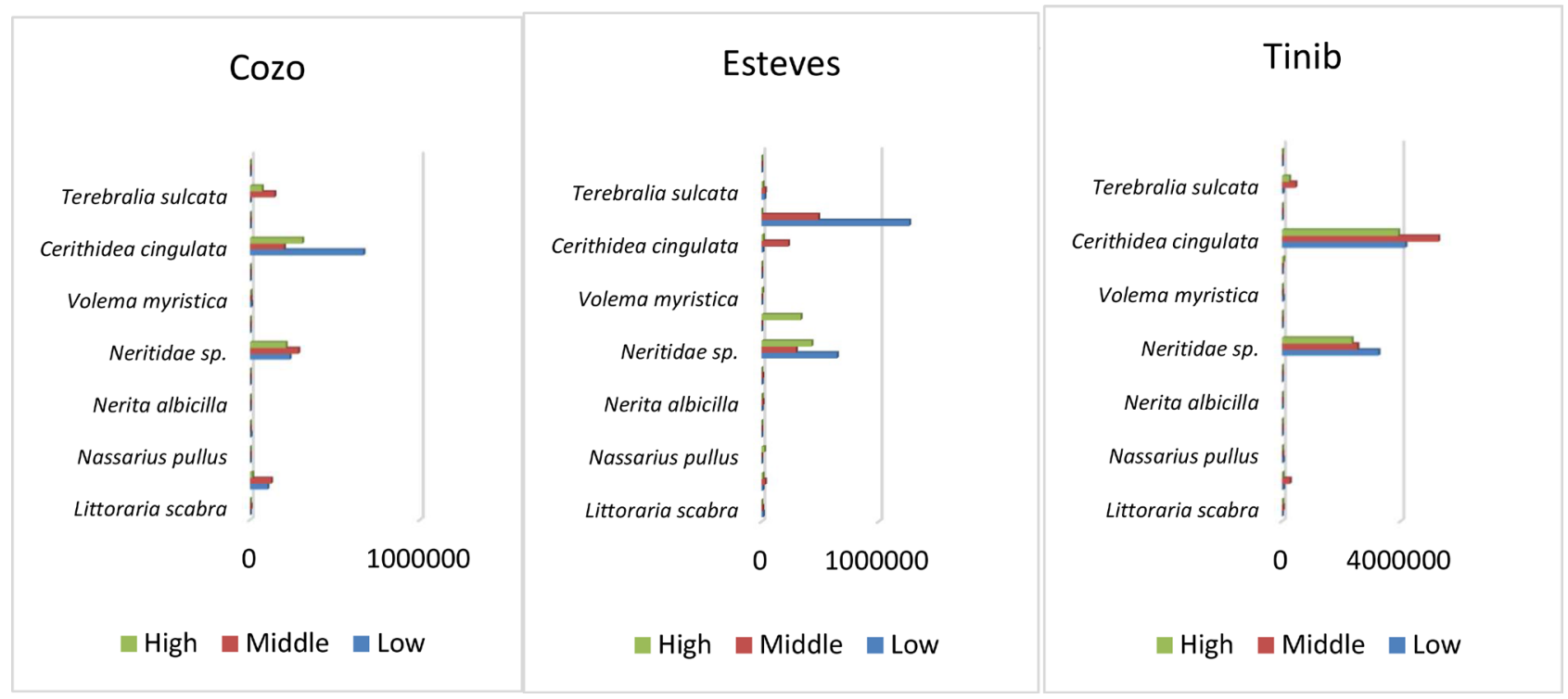

Figure 3. Density of gastropod species in different tidal zones of Cozo, Esteves, and Tinib mangrove forests. 
Figure 4 shows the relative abundance of bivalve species in different tidal zones of Cozo, Esteves and Tinib mangrove forests. The Cozo mangrove forest was dominated by Dendostrea folium that had a percentage abundance of $97.44 \%$ in the low tidal zone and $100 \%$ in the middle tidal zone. The $100 \%$ abundance was due to the fact that only this species was seen during the survey.

In Esteves and Tinib, the highest abundance of Gafrarium tumidum was found in its respective middle tidal zones (75.02\% and 100\%). This could be explained by the presence of only two species in the middle tidal zone of Esteves and a single species in the middle tidal zone of Tinib.

The most abundant species in the low and high tidal zones of Esteves were Gafrarium tumidum (73.68\%) and Laternula truncata (33.33\%). The latter species was observed only in Esteves and could probably due to its adaptability to the moist habitat of the high tidal zone avoiding desiccation. However, in Tinib, Gafrarium tumidum was most abundant in low (50\%) and high tidal (100\%) zones.

Figure 5 shows the relative abundance of gastropod species in different tidal zones of Cozo, Esteves, and Tinib mangrove forests. The most abundant species in the low (65.79\%) and high tidal (50.83\%) zones of Cozo was Cerithidea cingulata while Neritidae sp. was the most abundant in the middle tidal zone (37.44\%).

In Esteves, Terebralia palustris was the most abundant both in low (63.06\%) and middle tidal (44.48\%) zones. However, in the high tidal zone, Neritidae sp. was the most abundant (51.61\%). The abundance of this species in the high tidal zone could be attributed to its suitability to the moist environment and its facultative nature.
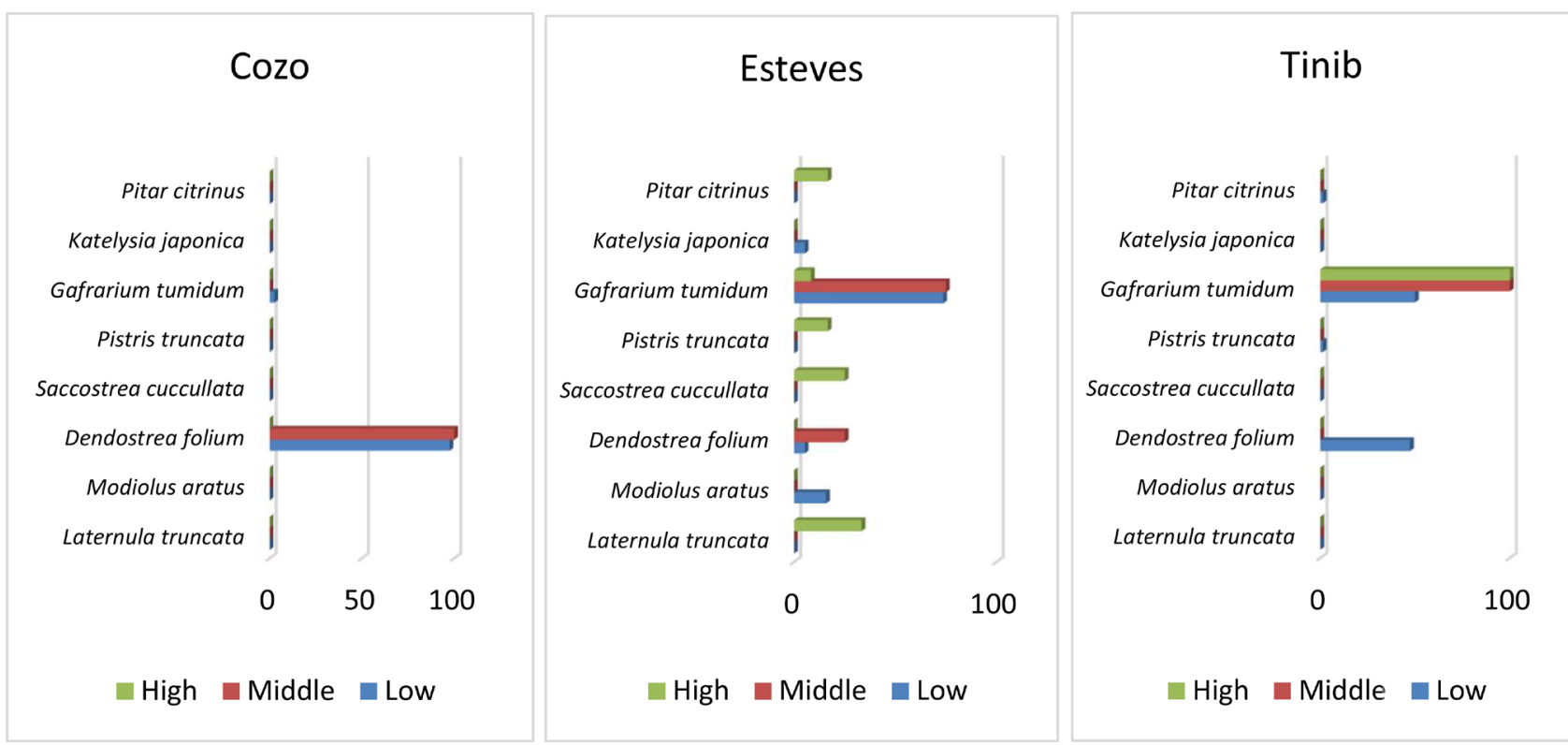

Figure 4. Relative abundance of bivalve species in different tidal zones of Cozo, Esteves, and Tinib mangrove forests. 


\subsection{Influence of Ecological Factors on Spatial Zonation and Diversity}

Figure 6 shows the similarity of bivalve species between tidal zones based on principal component analysis (PCA). Tinib Low Tidal Zone Replication 1 (TL1), Esteves Low Tidal Zone Replication 3 (EL3) and Cozo Low Tidal Zone Replication 2 (CL2) were clumped (green oval) since all these were within the low tidal
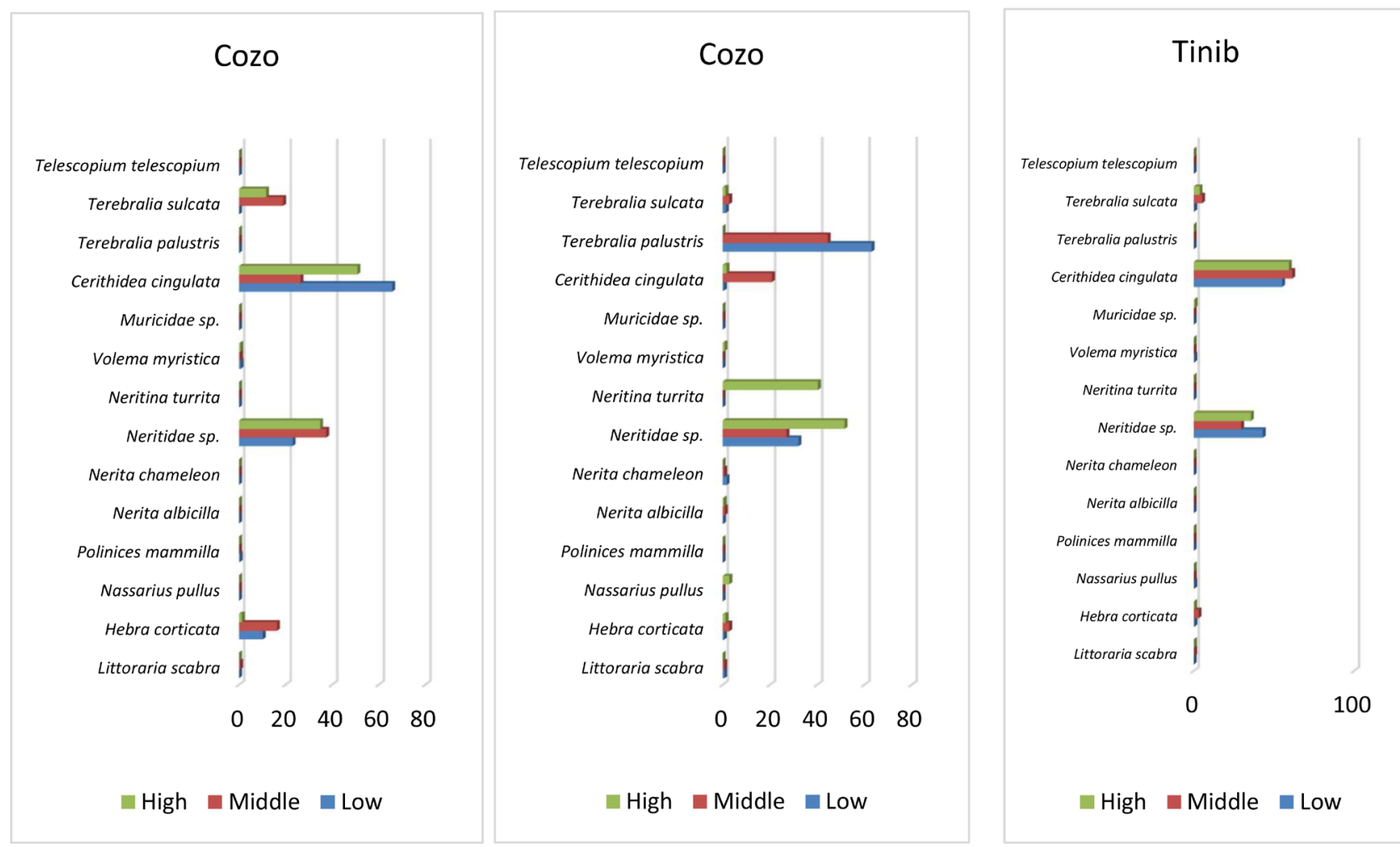

Figure 5. Relative abundance of gastropod species in different tidal zones of Cozo, Esteves, and Tinib mangrove forests.

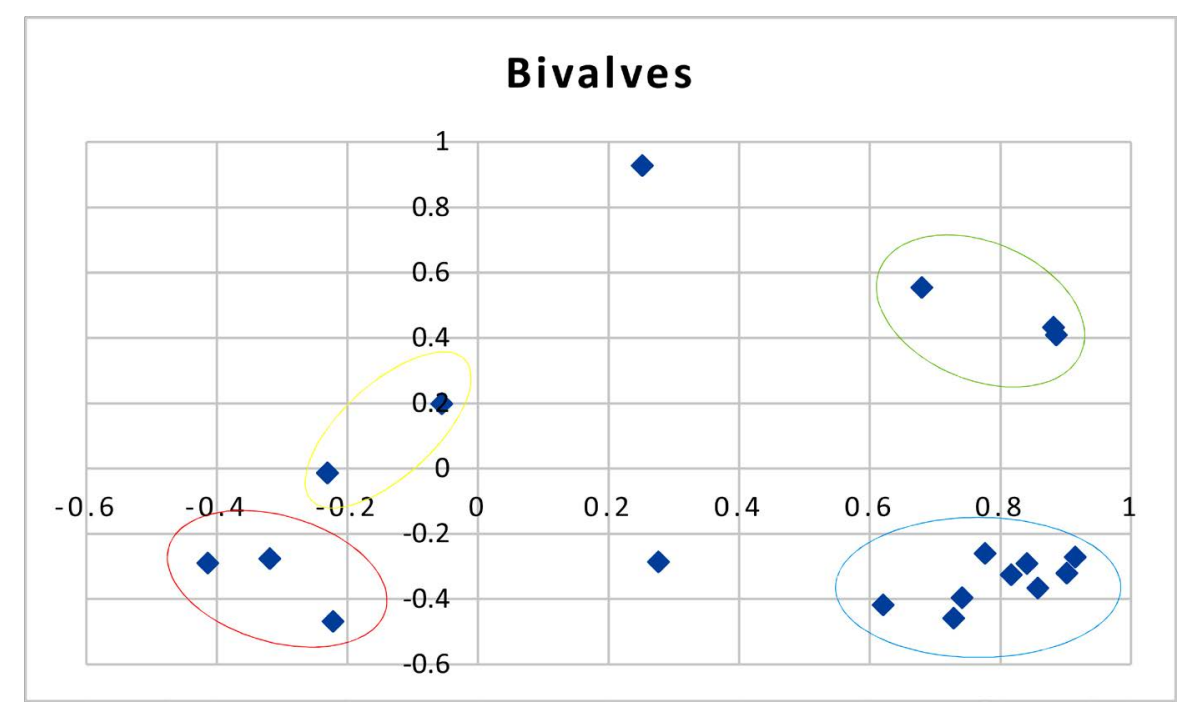

Figure 6. Similarity of bivalve species between tidal zones based on principal component analysis (PCA). 
zones and had sandy loam soil with high percentage of sand (65.55\% to $80.46 \%)$ with Gafrarium tumidum as common species. The high percentage of sand contributed the loose nature of mud that favored infaunal species like Gafrarium tumidum [14]. The mangrove areas whose bottom mud contains less sediment accumulation of organic matter and mud with loose nature are suitable for infaunal species. On the other hand, the very close clumping of TL1 and EL3 was due to the presence of both Gafrarium tumidum and Dendostrea folium. The latter species was observed clinging on young stems, leaves and pneumatophores.

Tinib Low Tidal Zone Replication 2 (TL2), Tinib Low Tidal Zone Replication 3 (TL3), Tinib Middle Tidal Zone Replication 1 (TM1), Tinib Middle Tidal Zone Replicaiton 2 (TM2), Tinib High Tidal Zone Replication 1 (TH1), Esteves Low Tidal Zone Replication 2 (EL2), EL3, Esteves Middle Tidal Zone Replication 2 (EM2), and Esteves High Tidal Zone Replication 2 (EH2) were clumped (blue oval) since all these zones had Gafrarium tumidum as common species in sandy loam to sandy clay loam soils, of which majority were within slightly saline soil (6.00 ppt to $9.00 \mathrm{ppt}$ ) with organic matter content ranging from $0.11 \%$ to $2.64 \%$. In addition, most of these zones were facing bodies of water either the ocean (TL2, TL3, TM2, EL2, EL3) or the river (TM1, TH1, EM2, EH2). The moist environment had favored the species to populate. The TM1 and TH1 were near the forking Montay river while EM2 and EH2 were near the flowing Calabgan river. The proximity of these zones to these rivers may have contributed their slightly saline soils. In addition, the clumping of mature mangrove trees in the middle tidal zones had maintained the mangrove floor moist favoring the presence of bivalves that are prone to desiccation.

Tinib High Tidal Zone Replication 2 (TH2), Tinib High Tidal Zone Replication 3 (TH3), and Esteves High Tidal Zone Replication 3 (EH3) were clumped (red oval) as these were within the high tidal zones with sandy loam soil of slight salinity (8.00 ppt to $9.00 \mathrm{ppt}$ ) and organic matter ranging from $0.90 \%$ to $1.82 \%$. On the other hand, Tinib Middle Tidal Zone Replication 3 (TM3) and Esteves Low Tidal Zone Replication 1 (EL1) (yellow oval) were both facing bodies of water such as the ocean (EL1) and river (TM3).

The results imply that Gafrarium tumidum is a generalist species that can live and reproduce in all moist tidal zones whereas Dendostrea folium can thrive in low and middle tidal zones with sandy loam soils of slight salinity (6.00 ppt to $9.00 \mathrm{ppt}$ ) and had mangrove saplings and pneumatophores where they could attach while feeding on algae [10]. The frequent tidal inundation in the low tidal zone favors the growth of benthic microalgae and macroalgae that serve as food for filter and deposit feeder as in the case of bivalves.

Figure 7 shows the similarity of gastropod species between tidal zones based on principal component analysis. EH3, EL3 and Cozo High Tidal Zone Replication $3(\mathrm{CH} 3)$ (violet oval) were located in sandy loam to loam soils of none (2.00 ppt) to slight salinity (5.00 ppt to $9.00 \mathrm{ppt}$ ), $\mathrm{pH}$ between 7.4 to 7.6 and organic 


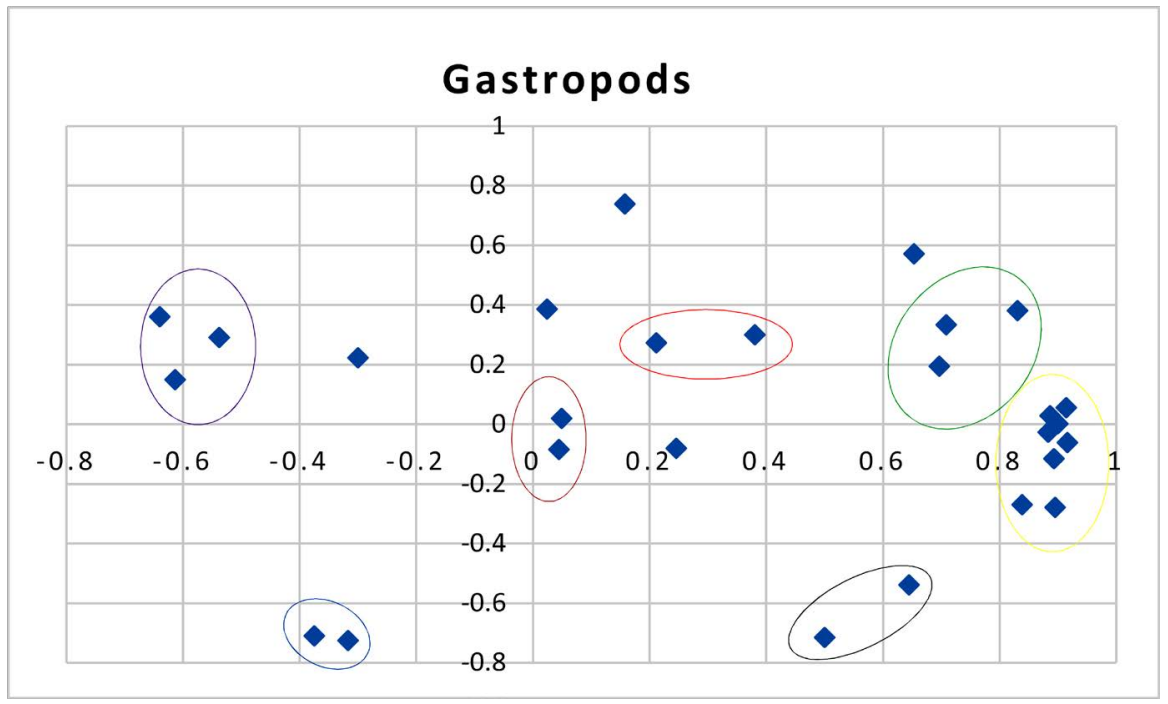

Figure 7. Similarity of gastropod species between tidal zones based on principal component analysis (PCA).

matter ranging from $0.11 \%$ to $2.00 \%$. The common species in these zones was Neritidae sp.

The Esteves Middle Tidal Zone Replication 3 (EM3) and EL1 (blue oval) were located in none saline (2.00 ppt and $3.00 \mathrm{ppt}$ ) sandy loam to sandy clay loam soils with $\mathrm{pH}$ of 7.6 and organic matter ranging from $0.57 \%$ to $1.16 \%$. These were also located in areas with mature trees were gastropods clumped at the base of the stem. The common species between these zones were Hebra corticata, Nerita albicilla, Nerita chameleon, Neritidae sp., and Terebralia palustris.

The Cozo High Tidal Zone Replication 1 (CH1) and Cozo Low Tidal Zone Replication 1 (CL1) (orange oval) were located in sandy loam soils of slight salinity ( $7.00 \mathrm{ppt}$ to $7.40 \mathrm{ppt}$ ), $\mathrm{pH}$ between 7.5 to 7.6 and organic matter ranging from $0.21 \%$ to $0.33 \%$. The common species between these zones was Neritidae sp. which is a facultative species that can live in mangrove forest and coastal habitat.

The Cozo Middle Tidal Zone Replication 1 (CM1) and Esteves High Tidal Zone Replication 1 (EH1) (red oval) were characterized with the presence of mature mangrove trees that serve as anchor for gastropod species during high tide. The soils in these zones were sandy loam of slight salinity (5.00 ppt to 7.40 ppt), $\mathrm{pH}$ of 7.6 and organic matter ranging from $0.19 \%$ to $0.41 \%$. The common species in these zones was Neritidae sp.

The TH3, CL2, and TH1 (green oval) were located in sandy loam soils most with high percentages of clay ( $16.51 \%$ to $18.43 \%)$ and silt (16.42\% to $28.53 \%)$ making the substrate muddy. The soils were of slight salinity (5.00 ppt to 8.00 $\mathrm{ppt})$ at $\mathrm{pH}$ ranging from 7.4 to 7.6 and organic matter ranging from $0.41 \%$ to $0.91 \%$. The common species of these zones were Neritidae sp. and Terebralia sulcata.

The TL1, TL2. TL3, TM1, TM2, TH2, CM2, CM3 (yellow oval) were all lo- 
cated in areas with mature mangrove trees where gastropods were seen attached to pneumatophores, clumped at the base and clinging on the stems. The soils in these zones were sandy loam, loam, and sandy clay loam of either none (5.00 ppt), slight (6.00 ppt to $8.00 \mathrm{ppt})$ or medium salinity ( $10.00 \mathrm{ppt}$ to $11.00 \mathrm{ppt})$. The soil $\mathrm{pH}$ ranges from 7.2 to 7.5 with organic matter content ranging from $0.49 \%$ to $2.77 \%$. The common species in these zones was Cerithidea cingulata. This species was also observed present in loamy sand or sandy loam soil but with higher organic matter (2.93\%) and a lower $\mathrm{pH}$ value of 6.8 in the study [14].

The EL2 and EM2 (black oval) were located in areas with mature mangrove trees in none saline (2.00 ppt to $3.00 \mathrm{ppt})$ sandy loam soils with organic matter ranging from $0.95 \%$ to $1.39 \%$ in $\mathrm{pH} 7.3$ to 7.4 . The common species between these zones were Littoraria scabra, Hebra corticata, Cerithidea cingulata, Terebralia palustris, and Terebralia sulcata.

This study covers only the species diversity, species equitability, population density, relative abundance, and similarity index between tidal zones in three mangrove forests located in Tinib, Esteves, and Cozo of Casiguran, Aurora.

\section{Conclusion}

Based on the results of the study, it is concluded that the mangrove forest of Casiguran, Aurora contains variety of bivalves and gastropods species, most bivalves species belong to Veneridae family while most gastropods belong to Neritidae and Potamididae families; the very low bivalve species diversity in all tidal zones of Cozo is due to the enormous density and abundance of Dendostrea folium, most bivalves in Esteves prefers the high tidal zone with very equal distribution, gastropods prefer the middle tidal zones in Cozo, Esteves and Tinib with almost equal to equal distributions, the density and abundance of Cerithidea cingulata and Terebralia palutris are due to their being strict inhabitant in the mangrove forest, all tidal zones within each study area have greater similarities in terms of bivalves but have greater dissimilarities in terms of gastropod species present, tidal zones between study areas have greater dissimilarities in terms of bivalves and gastropods present, and most tidal zones have Gafrarium tumidum as common bivalve species while Neritidae sp. and Cerithidea cingulata are common gastropod species that thrive in a wide range of soil salinity, organic matter, $\mathrm{pH}$ and texture.

\section{Recommendations}

For a more comprehensive study on bivalve and gastropod species spatial zonation and diversity in mangrove forests of Casiguran, Aurora, it is recommended that a survey may be conducted for 12 months to cover the changes in species diversity, equitability, density, and relative abundance during different seasons. It is also recommended that other ecological factors such as species of mangrove trees present, nutrient analysis of leaf litter and depth of tidal inundation may be included. 


\section{Acknowledgements}

The researchers would like to thank the Municipal Mayor and to the respective Barangay Captain of the study sites for allowing the researchers to conduct this study.

\section{Conflicts of Interest}

The authors declare no conflicts of interest regarding the publication of this paper.

\section{References}

[1] Kabir, M., Abolfathi, M., Zahedi, S., Kathiresan, K. and Goli, S. (2014) Effect of Man-Groves on Distribution, Diversity and Abundance of Molluscs in Mangrove Ecosystem: A Review. AACL Bioflux, 7, 286-300.

[2] Macintosh, D.J., Ashton, E.C. and Havanon, S. (2002) Mangrove Rehabilitation and Intertidal Biodiversity: A Study in the Ranong Mangrove Ecosystem Thailand. Estuarine, Coastal and Shelf Science, 55, 331-345. https://doi.org/10.1006/ecss.2001.0896

[3] Little, C., Williams, G.A. and Trowbridge, C.D. (2009) The Biology of Rock Shores. Oxford University Press, New York, 365 p.

[4] Carpenter, K.E. (1998) FAO Guide on Species Identification. The Living Marine Resources of the Western Central Pacific. Volume I: Seaweeds, Corals, Bivalves and Gastropods.

[5] Springsteen, F.J. and Leobrera, C. (1986) Shells in the Philippines. Carfel Seashell Museum.

[6] Okutani, K. (2000) Marine Mollusks in Japan. Tokai University Press, Tokyo.

[7] Gibbs, S. (2000) Salinity Notes. Salt Action, Forbes, South Wales.

[8] Nagelkerken, I., Blaber, S.J.M., Bouillon, S., Green, P., Haywood, M., Kirton, L.G., Meynecke, J.-O., Pawlik, J., Penrose, H.M., Sasekumar, A. and Somerfield, P.J. (2008) The Habitat Function of Mangroves for Terrestrial and Marine Fauna: A Review. Aquatic Botany, 89, 155-185. https://doi.org/10.1016/j.aquabot.2007.12.007

[9] Masagca, J.T., Mendoza, A.V. and Tribiana, E.T. (2010) The Status of Mollusc Diversity and Physical Setting of the Mangrove Zones in Catanduanes Island, Luzon, Philipines. Biotropa, 17, 62-76. https://doi.org/10.11598/btb.2010.17.2.77

[10] Beasley, C.R., Fernandes, C.M., Gomes, C.P., Brito, B.A., Santos, S.M.L. and Tagliaro, C.H. (2005) Molluscan Diversity and Abundance among Coastal Habitats of Northern Brazil. Ecotropica, 11, 9-20.

[11] Ashton, E.C., Macintosh, D.J. and Hogartht, P.J. (2003) A Baseline Study of the Diversity and Community Ecology of Crab and Molluscan Macrofauna in the Semantan Mangrove Forest, Sarwak, Malaysia. Journal of Tropical Ecology, 19, 127-142. https://doi.org/10.1017/S0266467403003158

[12] Lee, O.H.K. and Williams, G.A. (2002) Spatial Distribution Patterns of Littoraria Species in Hong Kong Mangroves. Hydrobiologia, 481, 137-145. https://doi.org/10.1023/A:1021241810526

[13] Bouillon, S., Moens, T., Overmeer, I., Koedam, N. and Dehairs, F. (2004) Resource Utilization Patterns of Epifauna from Mangrove Forests with Contrasting Inputs of Local Versus Imported Organic Matter. Marine Ecology Progress Series, 278, 77-88. 
https://doi.org/10.3354/meps278077

[14] Yijie, T. and Shixiao, T. (2007) Spatial Zonation of Microbenthic Fauna in Zhanjiang Mangrove Nature Reserve, Guangdong, China. Acta Ecologica Sinica, 27, 1703-1714. https://doi.org/10.1016/S1872-2032(07)60042-0 